\title{
Transferring Water While Transforming Landscape: New Societal Implications, Perceptions and Challenges of Management in the Reservoir System Franconian Lake District
}

\author{
Milan Daus *, Katharina Koberger, Nele Gnutzmann, Tobias Hertrich and Rüdiger Glaser \\ Physische Geographie, Albert-Ludwigs Universität Freiburg, 79085 Freiburg im Breisgau, Germany; \\ katharina.koberger@geographie.uni-freiburg.de (K.K.); nele.gnutzmann@students.uni-freiburg.de (N.G.); \\ tobias.hertrich@students.uni-freiburg.de (T.H.); ruediger.glaser@geographie.uni-freiburg.de (R.G.) \\ * Correspondence: milan.daus@geographie.uni-freiburg.de; Tel.: +49-(0)-761-203-3515
}

Received: 8 October 2019; Accepted: 19 November 2019; Published: 23 November 2019

\begin{abstract}
This study investigates the different stakeholder based discourses and challenges around the Franconian Lake District (FLD), a recently constructed large reservoir system in Germany. The construction and operation of reservoirs represent a massive alteration of their natural and social environments leading to discourses and potential conflicts between a wide scope of heterogeneous interest patterns. Studies have shown that large reservoirs can be an important contributor to water supply, irrigation, energy storage and therefore climate change mitigation on a global scale, which brings these conflicting interests to a broader societal concern. Yet, information about conflicts around existing (German) reservoirs is limited. To assess which issues and conflicts appear on the daily agenda and how they are perceived, communicated and addressed by the stakeholders, a total of 609 articles in the Nürnberger Nachrichten and 22 semi-structured expert interviews were analysed, using qualitative content analysis. The results show that discourses at FLD are predominantly determined by economic factors. Management issues are dominated by discussions about cyanobacteria, which can pose a health risk, thereby impeding recreational use of the lakes and consequently causing economic losses and an image problem for the region. The issue is also strongly interlinked with other aspects of concern and therefore one of the main challenges at the FLD. Due to the construction of the lakes and the evolving strong tourism sector, the formerly agricultural region was subject to a major structural change linking together a very heterogeneous set of interests. The results of this study can help in establishing a management framework to suit all stakeholders and possibly be transferrable to similar projects.
\end{abstract}

Keywords: Franconian Lake District; cyanobacteria; agenda setting; water governance; media analysis; semi-structured (expert) interviews; reservoir management; climate change mitigation

\section{Introduction}

Water and energy are two of the most important resources on our planet. Dams and reservoirs provide and store these resources based on the implementation of infrastructure to retain water. Due to population growth and changes in lifestyle the demands towards the watercourses are constantly rising and diversifying, incorporating interests like drinking and irrigation water supply, flood protection, energy production or navigational requirements [1,2]. It is estimated that around 45,000 large dams are currently built, planned or under construction worldwide, a trend that will likely accelerate in the future [3]. In Germany, dam construction with an emphasis on hydropower began around 1900 and reached its peak during the second half of the last century [4]. At present, there are 371 reservoirs 
that meet the ICOLD (International Commission on Large Dams) definition of large dams (15 $\mathrm{m}$ dam height or 3 million cubic meter storage capacity) [5].

To evaluate the challenges that go along with the planning, construction and operation process of reservoirs while taking today's societal demands into account is crucial in order to anticipate possible conflicts of interest and contested aspects regarding new projects as well as a better management of the existing ones [6-9]. The construction of dams and reservoirs does not only radically change the area directly affected, but the entire runoff system as well as the catchment area [10]. There is change in the flow regime, sediment deposition in the reservoirs, accumulation of nutrients in the (stored) water body, cyanobacteria blooms and methane and carbon dioxide emissions from the water column to name but a few $[10,11]$. The physical impacts of dams are not the only effects caused by this type of infrastructure- they also have a major impact on the social surrounding and the social networks in situ. This can be a change in the livelihood of people by flooding agricultural space, displacement of settlements for the artificial lake, shifts in social cohesion of the region and changes in the economic structure of the area [12-16]. These linkages between the natural surroundings and the former social structure, its adaptations due to the construction of the reservoir that result in a new network of demands and interests, is not yet understood. The pressing issue of challenges and potential conflicts arising while planning, building and managing these infrastructures however is inherent. Contested management decisions at reservoir locations illustrate a need for a better understanding of underlying discourse structures, stakeholder interests and possible communication pathways that enable the whole system to take differing viewpoints into account and anticipate possible conflict situations at an early stage. It also shows clearly that these considerations cannot be achieved from the outside, but that they have to be developed within the social systems from where they originate. Therefore, research presented here focused on a rather recently planned and built reservoir system in Franconia (Bavaria), Germany. This study represents a novelty regarding the Franconian Lake District (FLD) as a case study and the focus on the management implications of the reservoir as perceived by media and local stakeholders. By combining these two data sources it is possible to evaluate the discourses both from an individual, stakeholder based viewpoint as well as a product of an interpretation and selection process in respect to public communication and interest. As the outcome of the project may serve as an example for similar endeavours, it is important to identify those discourse characteristics. This led to the following research questions: What are the interests and positions of stakeholders? Which issues and discourses are present and relevant in the FLD and how did they develop over time? How is the reservoir system embedded in the region? What are the main challenges and is there a way to manage them?

Even though there are studies on mining pit lakes in Germany mainly focussing on physical water abilities [17,18] and agenda-setting [19], research on the effects of agenda discourses on management related issues by stakeholders/media around the FLD were not yet covered. As it affects a multitude of existing land uses and interests, it has also implications for future operation thus incorporating new needs and opening up a general discussion on how to develop the region and which concerns should take the lead. These considerations are linked to societal values and demands that are heterogeneous as well as dynamically changing $[20,21]$. These concerns appear on the regular agenda of local press and are discussed among the stakeholders involved. Both discourse dimensions are in constant interrelation with each other: The media influencing the discussion and vice versa. Or as Cohen phrases it " [ ... ] the press may not be successful much of the time in telling people what to think, but it is stunningly successful in telling its readers what to think about" [22]. This process of putting topics on the local agenda is one of the research key points within this study and draws on the growing literature about the concept of agenda setting, to closer understand challenges in management [23-29]. The following section provides a quick and general overview of the study area.

As the boom of dam construction in Germany has already exceeded its peak, it is necessary to look at established reservoirs and their implications. The FLD, planned in the 1970s and opened in the year 2000 , is one of Germany's largest water management projects. The systems primary function is to bring 
water from the Altmuehl and Danube catchment bridging the European watershed into the comparably drier Main (-Rhine)-Catchment [30,31]. It consists of several artificial lakes and canals, the centre being the Large Lake Brombach with its upstream dams Lake Igelsbach and Small Lake Brombach as well as Lake Altmuehl and Lake Roth (see Figure 1). Each year, around 25 Mill. cubic meters of water are retained in Lake Altmuehl and cross the watershed through a water conveyance tunnel into Lake Brombach [32]. Apart from maintaining consistent water supply and quality downstream, the system also offers flood protection upstream, hydro energy production as well as recreational areas [33]. Because of an increase in extreme weather conditions due to climate change like droughts, the importance of this water transfer is likely to rise in the future.

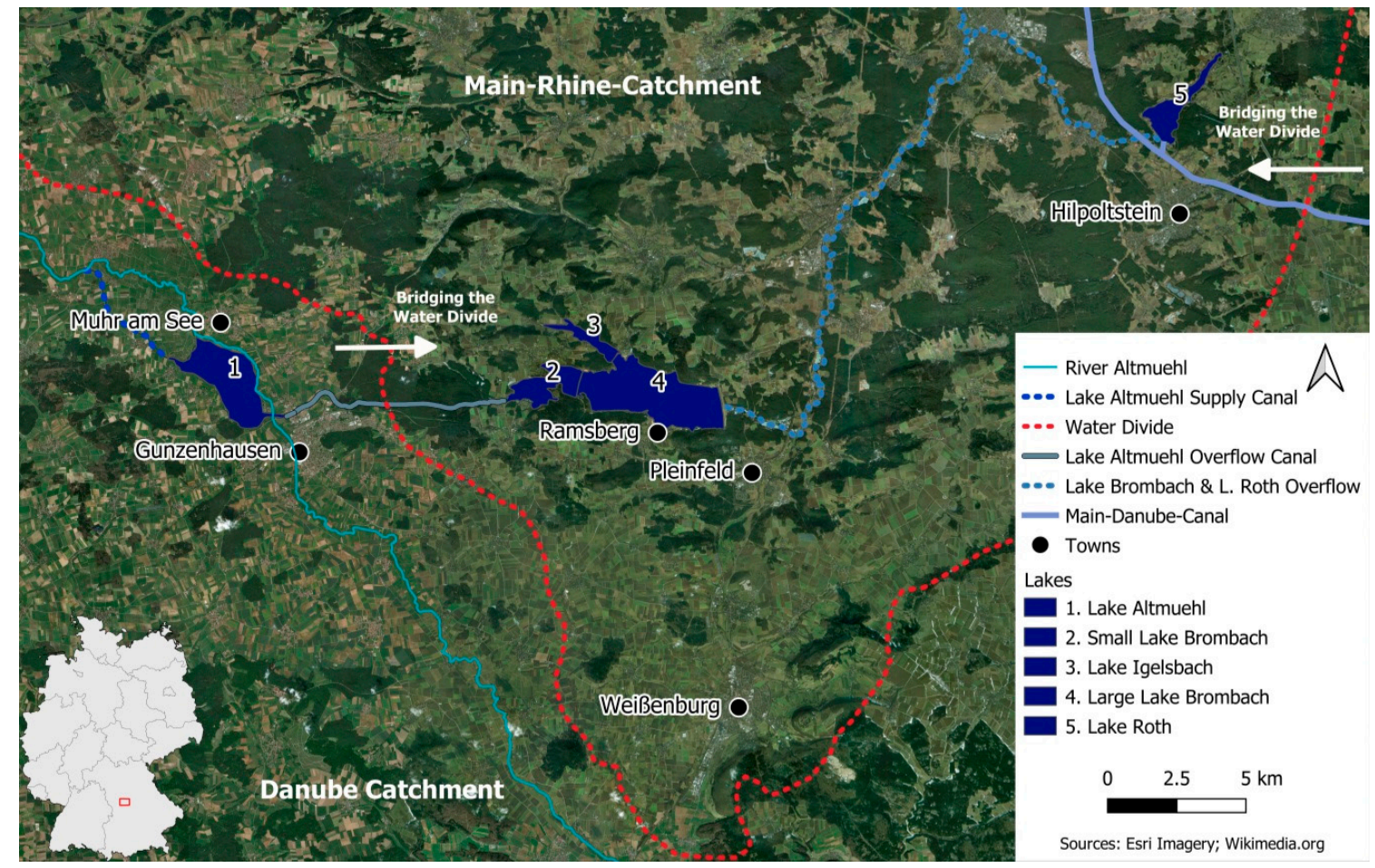

Figure 1. Overview of the study area.

Linking the catchments, the construction of the Brombach-reservoir system in Bavaria is comparatively recent. It offers ideal conditions to investigate and evaluate the changes and social consequences that accompany the creation of a large-scale hydrological project.

The construction of the reservoir system led to a radical structural change within the previously primarily agricultural cultivated region towards a strong touristic orientation adding stakeholder interests and additional demands [34,35]. Therefore, it is important to trace and understand the past, recent and present issues around this water levelling project.

\section{Methodology}

To provide these insights, a combination of different approaches was applied in order to gain a maximum of knowledge about the individual interests, needs and potential conflicting issues present. These demands should not be evaluated from the outside but with emphasis on the perceptions of the affected stakeholders and communities. The methodology has to be diverse and flexible to be able to approach the leading research questions from different angles.

In order to evaluate social perceptions and discussion trends in relation to the reservoir system and how they are communicated within the social environment, discourse analysis offers a suitable analytical framework. Based on the work of the French philosopher Michel Foucault, this concept states that a person's thinking and acting is influenced by superordinate societal value systems and 
collective ways of thinking [36-38]. The approach goes beyond the purely content-related level and also considers the underlying regularities, the social anchoring, power structures or the dynamics of certain discourse forms and arguments in comparison with each other as well as over time [39,40].

Different methods provide different scopes of data acquisition and potential information (see also Chapter 4.1). Expert interviews offer the most specific but also a largely subjective source of information. In contrast, media analysis considers information that is already a result of a social evaluation process of what is interesting for the general public and which information are distributed as the agenda setting approach suggests. As media contents mirror societal values and reflect current discourses, it is assumed that the occurrence of specific issues in the media coverage equally illustrates their importance for society [41]. Newspaper articles can hence be seen as indicators for relevant social topics [42,43]. Therefore, the different methods examine very different aspects of the social communication system.

\subsection{Expert Interviews}

The expert interview is a distinct form of a guided interview, where the interviewee is chosen due to his/her professional function $[44,45]$. As experts, their explicit knowledge and specific experiences are the objects of research and at the same time, the reason why they were interviewed $[44,46,47]$.

The criteria for stakeholder selection for the interviews was based on administrational/institutional responsibility, invested interests and proximity to the reservoir system [44,45]. Stakeholders were identified through newspaper analysis on the one hand and recommendation by other stakeholders on the other hand. Individual interview partners were determined by their institutional responsibilities and could not be requested or selected by the researchers. In total 22 interviews were conducted, transcribed and evaluated. Since the study area is presently influenced by a growing tourism sector, eight of the 22 interview partners are connected to this field. Managing and administrating the lakes and the area is another big issue so seven interview partners were affiliated with official offices and administration. Two interview partners came out of agriculture associations. Three interviews were held with nature conservation and there are another two interviews with local associations. Eighteen of the interview partners are male, four females (see Table A3 in Appendix A). An anonymization of the data was necessary to ensure requested confidentiality and thereby enhance data acquisition potential. The questionnaire was developed as a guided semi-structured interview, that combines comparable data acquisition by a predetermined interview flow with flexibility in respect to new or yet unknown topics introduced by the expert (see Appendix A) [44-46,48]. Expert interviews are not objective, as stakeholders per definition have certain interests concerning the reservoir. It is essential to anticipate and recognise possible agendas and viewpoints within the communicated information and appraise the material in a critical way. Additionally, individual interests might differ from collective ones which may or may not be recognised by people in question. The interview questionnaire focused on the role of the interview partner and the organization in respect to the FLD and followed a semi-structured setup intended to result in specific information about the management related topics (see Appendix A).

\subsection{Data Collection from Newspaper}

With 237,414 copies sold in the fourth quarter of 2018, the daily newspaper "Nürnberger Nachrichten" (NüNa) is the highest-circulation newspaper in the study area [49]. The decision for the investigation periods of the NüNa from 1 January 1990 to 31 November 2002 and from 1 January 2008 to 30 November 2018 was taken considering important events in the FLD. These include the phase of construction, the opening as well as currently relevant issues (increasing emergence of cyanobacteria, the heat and drought years 2011, 2015, and 2018, Seenlandkonferenzen (lake district conferences) with involved stakeholders 2009 and 2010). This list of events of interest was derived from information of literature studies and the semi-structured expert interviews.

To determine relevant articles in the NüNa a search in the online-database of WISO was conducted using the following keywords: Lake Brombach, Lake Igelsbach, Lake Altmuehl, Lake Roth and Fränkisch* Seenland*. Only completely available and relevant articles, no picture captions or (event-) 
announcements, were taken into consideration for the analysis. A total of 609 newspaper articles were included in the study and evaluation process

\subsection{Content Analysis}

To analyse the data systematically, a qualitative content analysis following Mayring $[48,50]$ was conducted, summarising and structuring interviews and media articles. Both were subsequently analysed using the social data analysis tool MaxQDA [51,52]. Within that application, a system of categories was established by the researchers based on the investigation focus. Different content categories are then assigned to text segments as codes [37]. This enables a comparative evaluation of the material, allowing a qualitative as well as a quantitative analytical approach.

Within this study, the category system was developed first theory-based (deductive) and additionally complemented through the coding of the first 50 articles as well as based on the interview material (inductive) $[37,50,53]$. The interviews were analysed using inductive methods, with a hypothetic-deductive setup [54]. As both, the categories and the codings are to a certain degree subjective, there is a margin of fuzziness. It is possible however to limit this fuzziness by focusing on main categories rather than sub-topics as they are generally more distinct and unambiguous. A total of 3710 codes were assigned to the 22 interviews, another 5851 codes to the media articles.

The results of the qualitative content analysis were interpreted, both qualitatively and quantitatively, using functions of the MaxQDA software package such as the amount and overlap operators [52]. In an additional step the data from the different methodological approaches has to be compared in order to identify consistencies and discrepancies. Both are of equal interest within the research as they point towards conflicted topics, possible methodological biases or can lead to stakeholder clusters regarding specific aspects and agendas. Some analysis opportunities are limited to one of the sources and cannot be applied to the other. For example, topics can be traced over time in respect to media articles while interviews carry more information on specific characteristics of stakeholder cooperation endeavours. A qualitative interpretation of text fragments was necessary to determine the overall category of the topic under discussion. As most aspects are interrelated, there is a degree of fuzziness at thematic boundaries. Categories were therefore decided by the main focus within the discursive spectrum.

\section{Results}

The analysis of the datasets reveals main discourses and stakeholder involvement at the FLD shedding light on a large variety of opportunities and challenges, which are illustrated in newspaper articles and interview data. There are three dimensions to this evaluation: the location the discourses are related to the stakeholders involved and the topics under discussion. In a second analytical step, the relations between these dimensions offer further insights.

To get an overview of the discourses connected to the lakes within this water management system as well as the constructed term Franconian Lake District as a whole, codes were created and included in the location categories allowing a quantitative evaluation. There are some notable differences in code numbers, both between the two data sets and between the location categories within the data sets (see Figure 2).

In terms of location references, interviews and articles show similarities with respect to the main lakes (Lake Altmuehl, Lake Brombach and Lake Roth) despite the difference in code numbers between articles and interviews. A major difference is the reference to the FLD as such. The newspaper articles tend to refer to the constructed geographical unit more often, whereas interview partners spoke more about specific lakes. This may point towards heterogeneous discourses at different locations within this technically as well as spatially constructed space and landscape. With the construction of the lakes, a formerly mostly agricultural used area, additional uses and stakeholders' interests were introduced. 


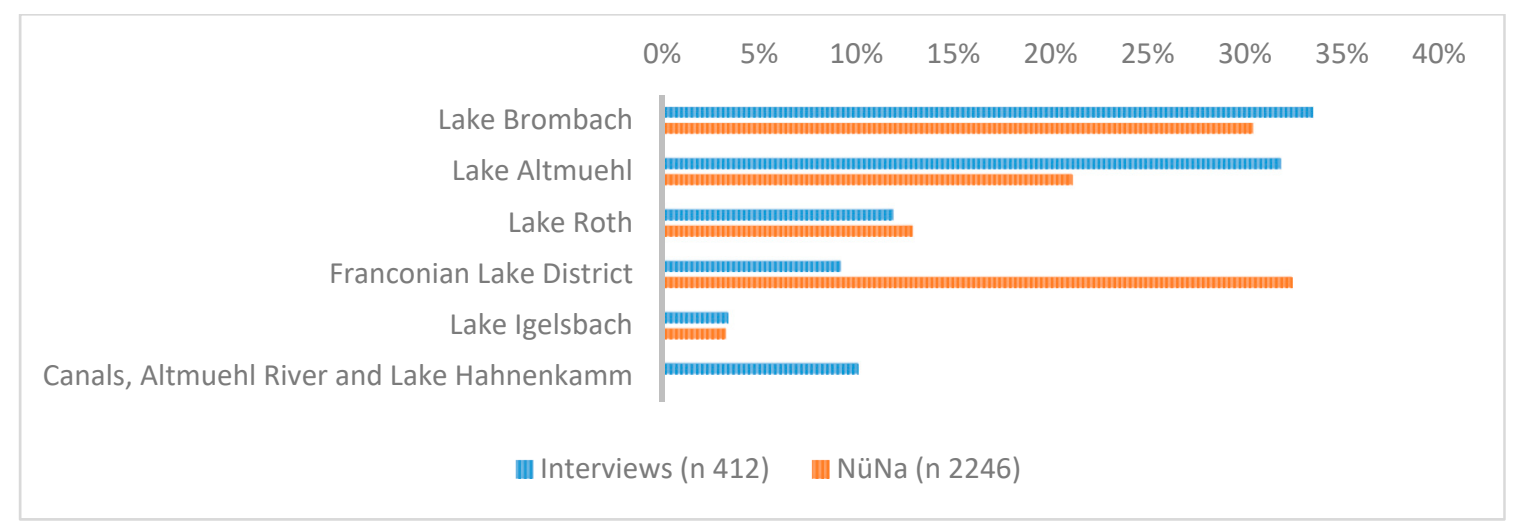

Figure 2. Distribution in percent of coded locations within the interview and NüNa data (Canals, Altmuehl River and Lake Hahnenkamm only coded in Interview data).

With the construction of the reservoirs, the group of participating stakeholders has become more diverse. This implies that new and secondary interests have to be taken into account. Due to data characteristics, coding of stakeholders differs between media analysis and interview evaluation. The media analysis takes direct stakeholder quotes into account, thereby enabling an evaluation of which stakeholders are capable to use the media most effectively and/or appear most prominently. Interview coding is based on stakeholders mentioned by the interview partner hinting towards communication and collaboration networks and quotation of personal/professional assessments.

The main stakeholder groups represent the participating organisations, institutions and individuals being active in negotiating and shaping the decisions and actions at the FLD. The distribution of coded segments with directly mentioned stakeholders presents itself as in Figure 3. Politics and administration ranks first which can on the one hand be explained by the administrational setting: the construction, ownership and management of the lakes is entrusted to state authorities that are divided into three separate administrative districts multiplying the number of associated institutions. On the other hand, the dominance of this group particularly in media coverage also hints towards the relative power of the group and its relation to the press. Despite the number of interviews in the different fields, agricultural stakeholders get mentioned the second most often, together with tourist stakeholders in the interview data. The share of directly mentioned administrational and tourist stakeholder in the NüNa points towards their importance shaping discourses in the FLD. In general, stakeholder involvement can result in emphasising certain topics and thus influence the agenda setting as well as discussion development and direction.

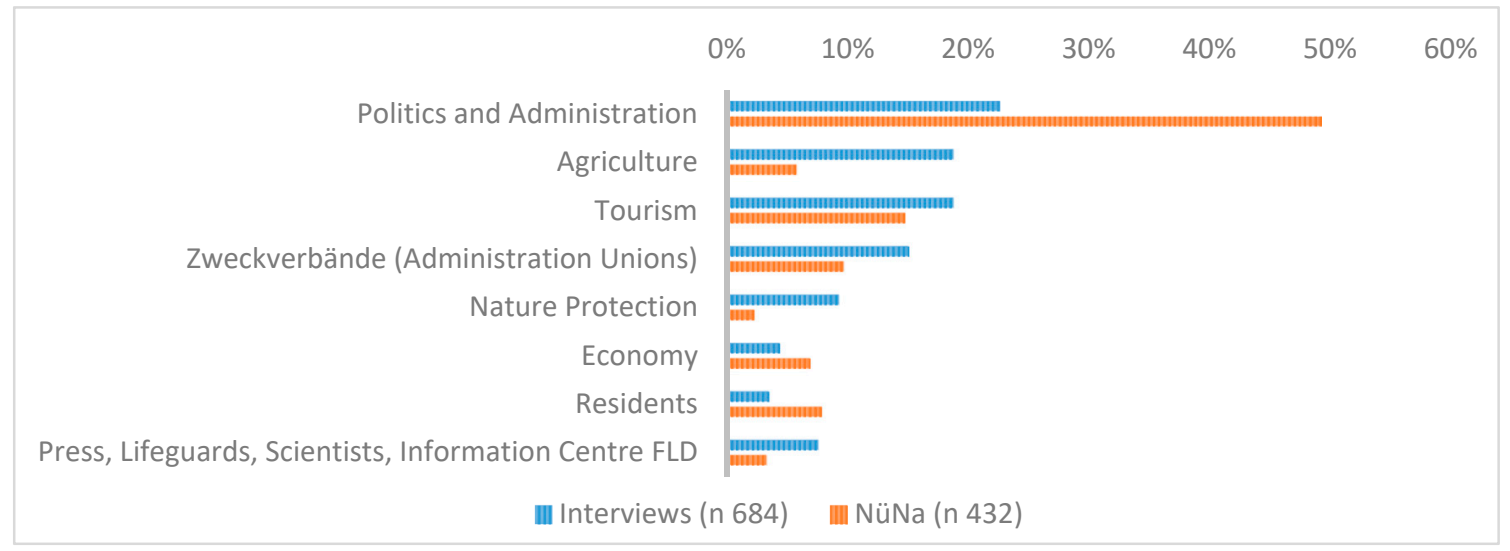

Figure 3. Distribution in percent of directly mentioned stakeholders in the interview and NüNa data. 
Besides location and stakeholder involvement, the specific topics under discussion form a third evaluative dimension. Discourses include a broad variety of topics and differ in part in the two datasets thereby offering additional evaluative potential (Figure 4).

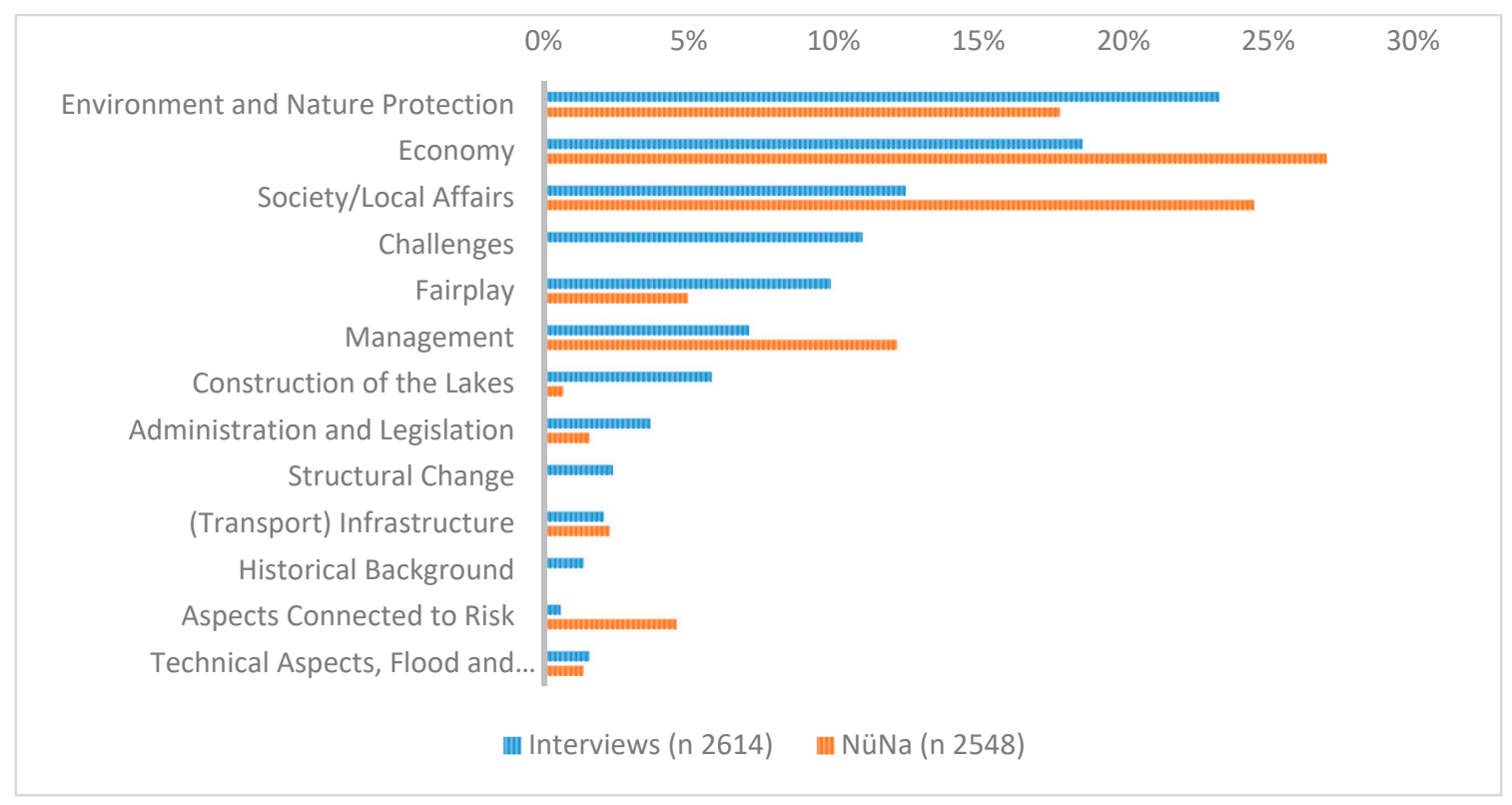

Figure 4. Distribution in percent of content coded categories in the interview and NüNa data (Challenges, Structural Change and Historical Background only coded in interview data).

The amount of coded segments in both data sources shows that certain aspects are subjects of a lively discussion, while others are not as prominent in the perception of the stakeholders and the coverage of the NüNa. The dominating discourses arise in environmental, economic, societal/local affairs, management and challenges/fair play categories, making up $82.4 \%$ of coded segments in interview data and $86.5 \%$ in NüNa articles overall. The environmental issues include topics like changes in the landscape, protected areas but predominantly natural phenomena mainly cyanobacteria and geese, both being directly connected to the FLD. The category Economy contains aspects connected to local value creation. Most importantly it includes Tourism as one of the most significant sectors in the study area with a multitude of connections to different features and factors. Local affairs summarises aspects that are of interest for local residents and is therefore well represented in the media as are management related aspects. The latter informs the public through the NüNa about water transfer matters, water quality matters and water level fluctuations in a descending order. The higher share of mentioned Aspects connected to Risk in comparison to the interview data could be explained by considering the media purpose of informing the public. Due to the different data source characteristics regarding function and purpose, challenges and fair play aspects are a category dominated by interview data, because they provide a more in-depth understanding of underlying situations and processes provided directly by stakeholders. As the analysis of frequencies in coded segments is a suitable way to get an overview of topics and discourses present at the lakes, further understanding can be created by analysing overlaps of categories and codes.

As a second evaluative approach, as shown in Table 1, the code overlapping function which combines content and stakeholder categories allowing for an analysis of discourse topics and participants thereby identifying key stakeholders and interests. 
Table 1. Overlap of content categories with most stakeholder quotes with main stakeholders in NüNa (red) and Interviews (blue).

\begin{tabular}{|c|c|c|}
\hline \multicolumn{2}{|c|}{$\begin{array}{c}\text { Content Categories with the Most Stakeholder } \\
\text { Quotes (Over } 25 \text { Overlapping Codes) }\end{array}$} & $\begin{array}{c}\text { Main Stakeholders (Overlapping Codes } \\
\text { between Stakeholder and Content Categories) }\end{array}$ \\
\hline \multirow[t]{3}{*}{ Fairplay (300) } & & $\begin{array}{c}\text { Water management offices (50) } \\
\text { Tourism (50) } \\
\text { Zweckverbände (Administration Units) (49) } \\
\text { Agriculture (40) }\end{array}$ \\
\hline & Cooperation (165) & $\begin{array}{c}\text { Tourism (33) } \\
\text { Zweckverbände (Administration Units) (31) }\end{array}$ \\
\hline & Dialogue (76) & $\begin{array}{c}\text { Water management offices (19) } \\
\text { Zweckverbände (Administration Units) (11) }\end{array}$ \\
\hline \multirow[t]{2}{*}{ Challenges (197) } & & $\begin{array}{c}\text { Tourism (80) } \\
\text { Agriculture (31) } \\
\text { Nature protection (29) } \\
\text { Administration (25) }\end{array}$ \\
\hline & Conflicts (114) & $\begin{array}{l}\text { Tourism (41) } \\
\text { Nature protection (24) } \\
\text { Agriculture (22) }\end{array}$ \\
\hline \multirow[t]{6}{*}{ Cyanobacteria (48), (111) } & & $\begin{array}{c}\text { Health offices (13), (7) } \\
\text { Water management offices (10), (22) } \\
\text { Agriculture (10), (55) } \\
\text { Zweckverbände (Administration Units) (11) }\end{array}$ \\
\hline & Occurrence (15), (16) & $\begin{array}{c}\text { Health offices (6) } \\
\text { Water management offices (3) }\end{array}$ \\
\hline & Causes (14), (32) & $\begin{array}{l}\text { Agriculture (8), (23) } \\
\text { Water management offices (4), (3) }\end{array}$ \\
\hline & Solutions (13), (32) & $\begin{array}{c}\text { Agriculture (13) } \\
\text { Water management offices (5), (7) } \\
\text { Zweckverbände (Administration Units) (5) }\end{array}$ \\
\hline & Health consequences (6) & Health offices (5) \\
\hline & General consequences (21) & $\begin{array}{l}\text { Water management offices (5) } \\
\text { Zweckverbände (Administration Units) (4) }\end{array}$ \\
\hline Building projects (42) & & $\begin{array}{l}\text { Administration union (12) } \\
\text { Mayors (6) } \\
\text { Politics and administration (5) } \\
\text { Residents (5) }\end{array}$ \\
\hline Touristic orientation (27) & & $\begin{array}{l}\text { Tourism Association (9) } \\
\text { Residents (4) }\end{array}$ \\
\hline Water transfer (25) & $\sum$ & Water management offices (20) \\
\hline
\end{tabular}

Overall, stakeholder involvement varies with the topic under consideration, illustrating a task related discourse environment rather than stakeholder based discourses (Table 1).

The predominant role of the executive offices in the NüNa cyanobacteria discourse shows the focus in the media coverage on official authorities and reveals the political dimension and attributed importance of this topic. The agricultural stakeholders appear prominently in the debate about causes of the problem. Altogether, it is a lively discussed topic shown by the high amount of overlaps to stakeholder as well as content categories 
Considering the amount of overlap between the lake categories and the content as well as stakeholder categories, main topics for each lake in the investigation period can be identified (Tables A1 and A2 in Appendix A). It has to be taken into account that there are different amounts of codes in each lake category.

While for Lake Roth primarily water management aspects and the corresponding stakeholders appear in the $\mathrm{NüNa}$, the Large Lake Brombach is additionally frequently mentioned in the contexts of its relevance for recreational and touristic purposes. At the Small Lake Brombach, Lake Igelsbach and Lake Altmuehl the discourse about cyanobacteria dominates. At the first two lakes the discussion is more influenced by touristic interests (high water quality for beach tourism) whereas at the Lake Altmuehl nature conservation aspects play a vital role. The leading discussions for the whole FLD reflect its touristic and therefore also economic value for the region and are led by mayors as representatives who balance regional interests as well as tourism associations. All in all, these location-related discourses mainly reflect the intended functions and purposes of the different lakes intended during the planning and construction process beginning in 1970 .

The water management is a much more self-contained topic than for example the cyanobacteria or the touristic orientation. There are little overlapping codes to other content categories or the stakeholder categories. This may hint towards clear management duties. Therefore, most overlapping codes are codes within the main category (e.g., overlapping between Water transfer function and Water storage (11) or Water level fluctuations (19)).

Media analysis allows a tracing of discourses or topics and their variation over time. The articles in which the respective category has been coded at least once were used to illustrate the temporal discourse dynamics (Figure 5).

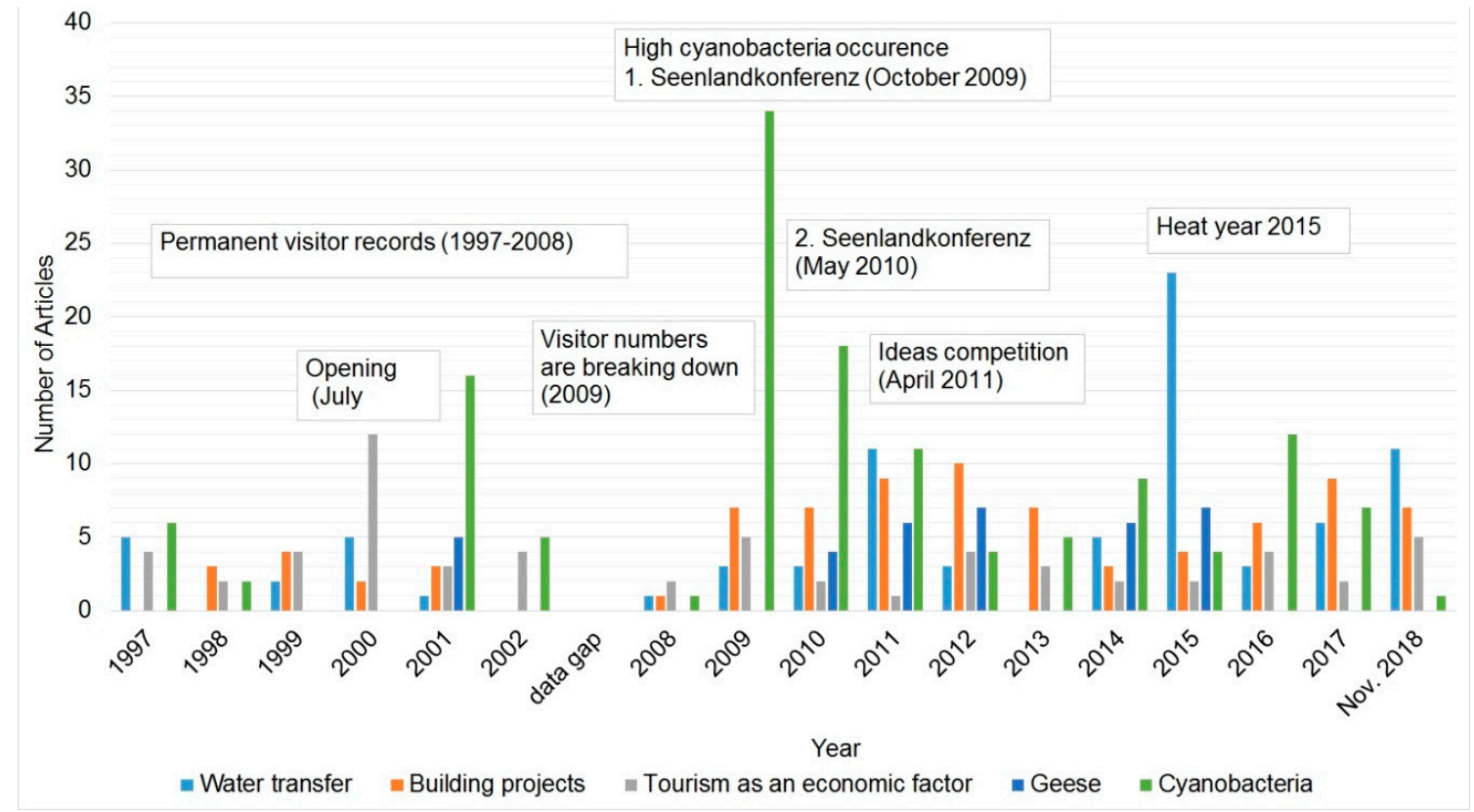

Figure 5. Number of NüNa articles per year on selected discourses over time (1997-2018).

Figure 5 shows notable topic-related peaks through the years highlighting discourse dynamics and perceived challenges. During the opening of the FLD in 2000, the category Tourism as an economic factor was predominant in the newspaper coverage. The project was headlined as: "Shooting star among the holiday regions, can look into a promising future. With the opportunities arising from tourism, the once structurally weak region has received unsuspected perspectives" [55]. Looking at the agenda setting ability of the newspaper it helped to establish a very positive view of the FLD during its opening period. In the following years, visitor numbers rose steadily establishing a strong touristic component and putting 
economic emphasis on this sector. That is why the decline in visitors in 2009 caused considerable concern among stakeholders. One reason among others for the reduction in visitors was pinpointed in the massive bloom of cyanobacteria in the summer of the year 2009. As touristic diversification towards water unrelated facilities was amongst the solutions stakeholders agreed upon, an idea competition was conducted in 2011 that was well covered in the media. In consequence, various building projects emerged and a general discussion on future touristic development (e.g., lakefront development, parking areas and blocked accesses) and re-orientation can be found in the NüNa. The re-orientation was mainly connected to a renewal and diversification of touristic offers. This might show the important agenda setting function of the newspaper and the connection to the parent discourse about making the FLD more attractive to various tourist groups. Another re-orientation in respect to new facilities as a reaction to changes in touristic demand structures can be seen in 2017. Even though the water transfer function was the main reason the reservoirs were built, the media has been paying comparatively little attention to this aspect. However, special conditions may put the water management topic on the agenda: the heat wave of 2015 for instance also resulted in a visible peak as the reservoir system contributed to mitigate the challenge of low water levels downstream of the lakes.

The results of the media analysis as well as the expert interviews show clearly, that there are a number of predominant discourses that are of concern to stakeholders and the general public (see Tables A1 and A2 in Appendix A). These are in part interlinked and are forming a discourse system. This discourse system is led by discourses about natural phenomena which impede other, mostly touristic, use of the water and the tourism sector itself, which in turn is influencing the water quality. The discourses about ecological topics centre mainly about blue-green algae (cyanobacteria) and the growing population of geese: "The Franconian Lakes are fighting on two fronts against their opponents: The Cyanobacteria in the water and the greylag goose on the lawns for sunbathing" [56].

\section{Cyanobacteria Discourse}

As shown above (Figure 5), the most prominent discourse at the FLD as indicated in the media analysis (42.5\% of all "Nature conservation" codes) as well as in the interviews (57.7\%) is about cyanobacteria. The relevance of the cyanobacteria issue is particularly apparent, when analysing code overlap between content categories (see Tables A1 and A2): the cyanobacteria category with its sub-categories' "Occurrence", "Health consequences", "Causes and Solutions" has in total the most overlapping codes with other content categories and is especially close to categories related to tourism, for example the "Beaches/bathing"-category. The interviews mirror the higher degree of expert knowledge with regard to the problem as they are emphasising the communicational and administrational component as well as distinct features that are connected to management approaches (e.g., sewage treatment plants).

The main connection of the discussion on cyanobacteria and the other content categories in the articles of the NüNa $(n=574)$ can be found in "beaches/bathing" $(8 \%)$, "water quality" $(7 \%)$, "risk due to use of the lakes" (6\%) and "natural phenomena as an image problem" $(3 \%)$. The analogue analysis of interview data draws a picture of deeper contention. Here, the overlap of the cyanobacteria code $(n=215)$ is connected to "challenges" $(13 \%)$, "conflicts" $(10 \%)$, "water quality" $(8 \%)$, "sewage treatment plants" (7\%) and "sediments" (5\%).

Cyanobacteria are a phylum of mostly aquatic bacteria that can form extensive visible bluish greenish carpets when in bloom [57]. Some cyanobacteria, described in the NüNa, can cause "Nausea, vomiting and diarrhoea [ ... ] Skin irritation and allergic reactions" [58] thereby posing a health risk. That is why the monitoring of bloom conditions is part of the Bavarian bathing water directive [59]. If necessary, bathing warnings/bans are implemented with serious adverse consequences to (water related) tourism and recreation [60]. The NüNa stated: "bathing warnings [due to cyanobacteria] [ ... ] angered holidaymakers, scared off excursionists and thoroughly spoiled the business of the tourism industry" [61]. In case of a reoccurring algae bloom, the uncertainty about bathing conditions may lead to a decline in visitors and image-loss as a dependable destination. Stakeholders recognised the importance of 
the cyanobacteria-issue in the FLD early on and it became the reason and one of the main topics discussed at the Seenlandkonferenzen in 2009 and 2010 as illustrated in the local media coverage at that time [61-63]. Several counter measures were discussed to be implemented, e.g., renew sewage system, introduce predatory fish to reduce whitefish, agricultural adaptations with respect to nutrient input, but also a more general touristic adaptation by diversification of the touristic offer in order to enhance the regions touristic value [64].

In addition to environmental factors like temperature or oxygen supply, nutrients are a crucial influence in respect to cyanobacteria bloom. Even though precise nutrient ratios for large-scale cyanobacteria blooms are still unknown, the need for identifying and managing the nutrient input is key to mitigate harmful blooms. Therefore, the emission pathways of nutrients (nitrogen and phosphate) play an important role in the discussions and do lead to frictions among stakeholders. Agriculture has been indicated in the NüNa as a main contributor [65], but reducing nutrient input would lead to restrictions regarding fertilising and thereby possible crop yield and income losses. Farmers contest being blamed for the problem and voice their opinion via newspaper as well, pointing out, that overall processes are not yet fully understood and e.g., sewage treatment plants and geese may also be relevant [66].

The cyanobacteria problem is even more emphasised if general concerns of water quality are taken into account as well. Water quality is almost exclusively discussed in relation to tourism, it is therefore not perceived as an ecological issue but an economical one. As a consequence, cyanobacteria are depicted as an image problem for the FLD and the discourse mainly centres around their negative impact on touristic offers according to NüNa as well as interview data.

The dependence on suitable bloom conditions lead to spatial distributions patterns: Lake Altmuehl is particularly vulnerable to cyanobacteria blooms due to its shallow water depth (average $2.5 \mathrm{~m}$ ) and consequently high water temperatures, as stated in the NüNa [67-69]. This is clearly indicated in both datasets, thereby illustrating a location-based discourse characteristic. A look on relative code distribution further highlights the cyanobacteria issue, as it is the main discourse at Lake Igelsbach and Small Lake Brombach as well (see Tables A1 and A2 in Appendix A).

The NüNa articles trace the locations of cyanobacteria blooms over the years. Lake Altmuehl in particular is associated with this phenomenon $(46 \%, n=94)$. It is furthermore mentioned in connection to the Small Lake Brombach (18\%), FLD (15\%) and Lake Igelsbach (11\%) in general. The other lakes only play a minor role in this discourse as they have not been affected so far.

The characteristics of a topic under discussion may be very different, if distinct elements of discourses are evaluated by establishing and evaluating subcodes. The evaluation of these characteristics in a quantitative but also in a qualitative way is vital to understand the real concerns and key aspects within one topic. Understanding the perceived issues concerning cyanobacteria can be done by subdividing the code into Causes, Occurrence, Consequences and Solutions and compare those on the two data sources. The differences between the two datasets show discourse dynamics and heterogeneous communication goals. Since the interviews specifically asked experts about the challenge that cyanobacteria pose, the answers were more elaborate, which led to additional categories as monitoring and general consequences.

In contrast to the interviews, the media focuses mostly on the occurrence of cyanobacteria, by publishing their locations (Figure 6). There is also a stronger focus on health and safety warnings in the NüNa than in the interviews. The relevance of Causes and Solutions is nearly similar in both data sets.

Interestingly the category listing possible solutions to the algae problem as well as the category on probable causes are strongly represented hinting to similar discourse characteristics in both data sets. As the issue is of high importance in the FLD, there have been several joint endeavours by multiple stakeholders to not only understand the origin of the occurrence, but also establish counter measures and an organisational framework in respect to communication pathways and ad-hoc procedures. 
(a) n 321

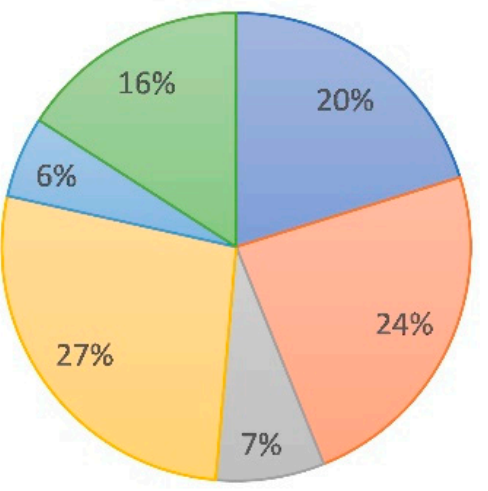

$\begin{array}{ll}\square \text { Occurence } & \square \text { Causes } \\ \square \text { Health Consequences } & \square \text { Solutions } \\ \square \text { Monitoring } & \square \text { Consequences }\end{array}$ (b) n 179

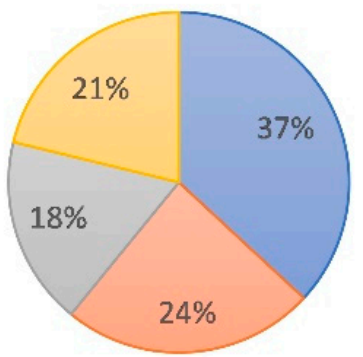

口Occurence

$\square$ Causes

$\square$ Health Consequences

$\square$ Solutions

Figure 6. Percentage of sub codes in category Cyanobacteria in (a) interview $(n=321)$ data and (b) NüNa $(n=179)$.

If broken down to single topics in the categories Causes and Solutions of cyanobacteria blooms in the interview data, a set of statements can be observed concerning the understanding of the why and the how of cyanobacteria in the FLD. The interview data concentrated on issues being mentioned at least five times by different stakeholders. The perceived "causes" of the cyanobacteria bloom concentrate on land use in its broadest sense, with strong emphasis on agricultural use in the area (mentioned 16 times), other land use like construction sites (7), biogas plants (6), sewage treatment plants (8) and the superordinate topic of nutrients being transported into the lakes out of these sources (9). Agricultural stakeholders see the causes mainly in the general land use of the area. Touristic stakeholders mainly mention biogas plants, while nature protection and administration stakeholders see agricultural use as a main source for the cyanobacteria blooms.

The solutions sub code in cyanobacteria superordinate code presents itself in solutions connected to enhance sewage treatment plants phosphate precipitation (13 times), solutions connected to the "Seenlandkonferenzen" (8), diversification of touristic offers (7) and sediment removal (6) dominate the discourse. Interestingly, the direct solutions to the causes do not necessarily reflect the perceived causes. The solutions are dominated by point source pollution decimation with improving and renewing sewage treatment plants. Another technical solution is sediment removal from the lakes. Whereas, "soft solutions" like communication and diversification of (touristic) offers is a different approach in mitigating societal effects of cyanobacteria blooms.

The quantifiable nature of counting distribution and frequencies of codings provides an overview over topics and discourse and how they emerge over time or within a group of stakeholders. To provide a deeper understanding, it is important to provide qualitative statements, which can be generalised over different interviews and newspaper articles.

Since the Causes and Solutions sub codes represent a personal and explicit knowledge, and a personal or institutional agenda, respectively, these statements of opinion have to be integrated into the analysis. As shown above, nutrient emissions are perceived as the primary cause of the cyanobacteria blooms. However, further analysis paints a more diverse picture if statements are analysed in detail, as the following example illustrates. A representative of the administration group states: 
One has to admit honestly, that the share of input due to agriculture is not insignificant. Because the Altmuehl [river] has special characteristics. It is a reverse river, that is to say, it has little flow gradient. And if a thunderstorm sheds $100 \mathrm{~L}$ of rainwater, it will flood adjacent areas. And it takes everything in these areas with it. [ ... ] And then it flushes everything [... ] into the lake where it deposits. [70]

In the sub code Solutions to cyanobacteria, there are similar patterns within the groups as well as within the most stated answers to the problem. As shown above, the solutions to the problem target the reduction of nutrients in the water and diversifying dialogue, cooperation and touristic offers. As an interview partner from the tourism group states:

The measures were tested in different areas. In a touristic context one looked for offers that are independent from water quality in order to establish alternatives to a mere beach holiday. [ ... ] Measures were also taken in a water management context. This is mainly the responsibility of the water management office. Less nutrients should enter the lakes. For example, the flood waves in springtime should no longer be directed into the lake and such. And then there are measures in an agricultural context. To counsel farmers that they won't cultivate their land intensively, that they plant appropriate crops, that they won't necessarily put slurry on areas adjacent to rivers. But all these are voluntary measures in an agricultural context. [71]

This statement shows the knowledge and expertise required to deal with the problem. But even with all this knowledge and solution oriented thinking, it is still a process of mediating all the different interests at the FLD in order to deal with the challenges connected to cyanobacteria and provide solutions fitting most stakeholders. This may include voluntary solutions in addition to technical ones with the implementation of phosphate precipitation at sewage treatment plants.

Another ecological challenge is oftentimes mentioned in connection with nutrient input: the FLD has issues with flocks of grey geese that use the area to breed and feed. Furthermore, some geese which spend the winter in Munich visit the FLD for a daytrip, posing a year-round occurrence [72,73]. This invasive species causes considerable damage to agricultural land [74-76] and their excrements soil recreational areas leading to cleaning costs and disgruntled tourists $[77,78]$. Media as well as interview data indicate that all stakeholders, including nature protection, perceive the geese as problematic and an issue that should be resolved. The geese issue was also discussed in connection with the cyanobacteria discourse, in particular during its peak in 2009, as excrement contribute to the nutrient input. However, water management offices as well as scientists came to the result that the geese excrement cause not more than five percent of the amount of nutrients in the lake water [63]. After 2015, the geese are scarcely mentioned in the newspaper anymore even though the issue is not yet solved (Figure 5) [63,66].

\section{Discussion}

This research focused on societal perception and interests connected to a modern reservoir system in south western Germany. The combination of media evaluation and semi-structured expert interviews with qualitative content analysis by MAYRING provided a deeper understanding on how discourses are being initialised and reproduced in groups of people professionally affiliated with the water levelling project as well as communication pathways and information requests by the public. The analysis incorporated a multitude of stakeholders enabling an evaluation of which sectors benefit and which sectors are adversely affected by the construction of the lakes in the region of the FLD. Furthermore, the research found information on the main areas of conflict and dissent as well as dialogue and cooperation between stakeholders around the lakes. During construction, but also after the completion of the FLD there are several benefits and disadvantages addressed by different stakeholders in the reports of the NüNa. A few residents, the tourism branch and politics (state government and municipalities) identify a clear benefit in the project (water storage and transfer function, touristic development, upgrading and development). Some local residents (in particular 
former mill owners), nature conservation and agricultural representatives doubt that the benefits of the project will surpass (their) personal and/or societal disadvantages (relocation, loss of land, landscape change, habitat degradation).

As the project caused a fundamental change in land use, it might have been very much contested by the local stakeholders like nature protection groups and residents. Due to the reservoir, mainly agricultural areas were lost, but there were also eleven mills whose residents had to relocate [79]. However, compared to the large scale conflicts and discourses surrounding even small management changes at reservoirs today (e.g., water level fluctuations at Schluchsee in the southern Black Forest, Germany), the opposition was relatively minor [80-82]. In the case of the FLD, the concerns are mostly driven by limitations in touristic use, implying an economically influenced point of view that is shared by many stakeholders, thereby impeding alternative perspectives from rising to the surface of the agenda. It is striking how most topics of the discussion relate to this key sector which is especially unusual with respect to ecological factors as an image problem. The cyanobacterial blooms only receive such attention because of the strong tourism sector within the FLD. Since it is still not entirely clear how blooms form, there is a strong focus on this research $[57,83,84]$. Generally, implications of dams on a social scale have been researched elaborately. The research on the impacts of dams are mainly focussed on resettlement implications of large dams in Asia and often favour livelihood or financial aspects [33,85-87].

Even though the main function of the reservoir system is the water transition, it is not predominant within the discussions as it usually does not impede other usages. The water administration offices actively support touristic interests, e.g., by channelling flood water that carries high concentration of nutrients past the lakes, thereby mitigating the risk of cyanobacteria blooms [88]. This has positive effects on the discourse atmosphere in general: the administration offices are viewed very favourably by most stakeholders which enhances collaboration potential.

The importance of the tourism sector is evident in all analytic results. It plays a major role during the construction/opening period until today and directly or indirectly links most aspects. There are several possible explanations: (1) an increase in acceptance influenced by supporters of the project, (2) an indicator for number of stakeholders potentially involved in tourism and (3) a main interest of readers among others as economic topics are perceived as major issues at dams within contexts of the global north considering even removal of dams [89]. Therefore, the main potential for conflict lie within the tourism as well as the agricultural sectors that have to be taken into account in order to ensure a successful cooperation of all interests involved.

It is noteworthy, that nature conservation only plays a minor role in the discussions, which is unusual for recent discourses about large scale projects. Within the media there are few examples of direct quotes by that stakeholder group. Mostly it is other stakeholders speaking about nature conservation aspects. Even though interviews with nature protection protagonists took place, these aspects are still less intensely represented within interview evaluation as well. Again, those aspects that are mentioned are mostly related with touristic interest e.g., geese issues and the nature protection area "Vogelinsel" (Bird Island). The amount as well as the manner of reporting the articles of the NüNa can count as one source of setting an agenda [90]. For example, Horst M. Auer writes in the NüNa about the protest of some conservationists:

"The little group was small and gathered late enough, actually much too late: In late summer of 1990, a handful of people with banners, leaflets and a small wooden Noah's Ark stood on the grounds of the future Large Lake Brombach seeming quite lost. The fighters for natterjack toad and marsh clubmoss protested in the midst of sand piles and dredging lakes against an "economically nonsensical and ecologically unacceptable mammoth project". [91]

Another issue regarding economic development on site is real estate, more specifically the construction of new touristic infrastructure. The Tourism Association is committed to build more high-class hotels, especially hotels at the lakefront, to increase quality standards in general and to 
develop new facilities to meet changing touristic interests [92]. The Lake District is said to be vulnerable to adverse weather conditions because of its strong emphasis on beach tourism and has to diversify its touristic range beyond that focus [60]. Lakefront development is seen critically from the administration unions [60] and some residents [93]. Local residents perceive the expansion of the tourist target group as a threat to the popularity of soft tourism and fear a loss of atmosphere around the FLD [93].

\subsection{Methodological Constraints and Limitations}

Each methodological approach has certain advantages and limitations that may be relevant to data analysis and result interpretation as shown in Chapter 2. The results of the media analysis should be viewed critically in the context of the characteristics of the data itself: owing to the length of an article, public media tend to present connections and facts in a simplified way for the benefit of comprehensibility. There will be an emphasis on "media-effective" problems and there is presumably an interest of the people involved to be perceived positively by the readership. Therefore some interests groups may be over- or under represented.

Considering discourse analysis theory, stakeholders or topics that are not mentioned are just as important as the ones present as they reveal reproduced and therefore hegemonial but also non-hegemonial discourses [40]. Because of the heterogeneity of interests, agendas and management implications, it is important to gather qualitative data to ascertain a level of information on impacts, stressors, challenges and chances around the lakes of the FLD which are able to grasp the dominating issues. Since several of the impacts and concerns as well as chances are difficult to quantify it is important to recognise different narratives to understand the diverse picture of the project overall. Those methodological steps were also applied in different studies but with a focus on other countries of the world and especially the global south [33].

Therefore, several steps were taken to ensure high accuracy and consistency of the methodology by reducing adverse effects of subjective coding by different researchers. The lack of digital availability of articles in the 1990s represents another limitation of this research in analysing older discourses.

Data acquisition was influenced by some preconceived aspects: keywords in case of media analysis and the interview guide. The strong representation of location codes in the media analysis can be explained by the keyword search (Tables A1 and A2).

Interview data evaluation has to take some differences in data acquisition into account: (1) data was gathered during three separate field trips, (2) Interviews were conducted by different researchers, (3) five interviews were held via telephone, (4) four interviews have a stronger emphasis on cyanobacteria and (5) interviews differ in length $(<20,000$ and $>60,000$ characters). However, a comparison of coding characteristics between interview transcripts shows that they are indeed similar in respect to relative amount of codes with different character counts.

Comparison of the results originating from two very distinct data sources has certain limitations. Interviews are strongly influenced by the researchers as topics are not entirely freely chosen by the interview partner but follow a predetermined questionnaire. As each answer will also be coded, this influences the data analysis as well. Therefore, it is less useful to evaluate interview material by counting single appearances of a specific topic in the document. With respect to media analysis however, this kind of evaluation path offers insights into the distribution of certain aspects.

Some analytic topic categories are very reasonable for one data source, but do not apply for the other. Therefore, it was necessary to add, modify or subtract certain sub-categories leading to a slightly altered set of sub-categories within interview and media analysis. To counteract this, there was no initial quantitative evaluation of subcategories but only superordinate ones which are the same in both data sets to reveal similarities and differences. The differing categories were then qualitatively evaluated.

A commentary in the NüNa from 30 July 1990 criticises the putative positive and glorifying coverage by the NüNa. The comment suspects positive press to be necessary to cover up and support this million Marks project to still guarantee acceptance in the public [94]. This highlights the question 
whether newspaper coverage instigated and heightened awareness for this particular issue or just depicted present concerns and topics.

The question of who takes the lead in media communication and which ideas and concepts should be communicated to the general public was a concern among stakeholders and one topic under discussion at the Seenlandkonferenzen. Before, differences in opinion e.g., regarding the origin of the cyanobacteria problem were published by individual stakeholders leading to publicly waged conflicts thereby impairing stakeholder relations and joint solution evaluation. It was agreed that the tourist association will communicate aspects regarding cyanobacteria thereby organising communication lead and responsibility but also reducing heterogeneity of voiced opinions. Another conflict lays in general representation of the holiday region in contrast to municipal economic interests regarding tourism. While the tourist associations argue that the FLD is in competition with other holiday regions and has to emphasise a big picture of heterogeneous recreational offers and diversity, municipalities have an interest in marketing their own facilities. Even though it was agreed upon that the region should be advertised under the constructed term FLD, this joint venture of all municipalities is not yet without opposition.

\subsection{Governane Implications}

In summary, the FLD is seen rather positively by most stakeholders involved. This is emphasised by the fact that most issues deal with aspects that impede the use of the reservoirs, while the existence of the reservoir system itself is rarely questioned. Even nature protection and agriculture who had to suffer large constraints due to the project are generally content with the new possibilities the restructured area offers $[75,77,95]$. Due to the establishment of a tourism sector as well as flood protection, benefits could be achieved locally even though the projects main function generates benefits for downstream riparian. This strongly affects acceptance of the reservoir system in contrast to other locations. Issues impeding this touristic value are therefore observed with great concern as tourism is now the economic basis and there is a strong dependence on that sector. Most of the issues shown in this study are directly or indirectly linked to this main sector.

Nevertheless, there are several factors that have adverse impacts but are not yet debated by most stakeholders or the general public. Scientifically recognised relevant topics related to reservoirs like biofilm formation or greenhouse gas emissions so far have failed to reach the general public. On the other hand, clearly visible effects like sedimentation processes are an issue at the shallow Lake Altmuehl causing friction between water retention interests, tourism, agriculture and nature protection [88]. The discourse structure around the different positive and negative subjects concerning the artificial lakes is constantly diversifying with more stakeholders getting involved with possibly conflictive interests on how to use the lakes. In this sense, public decision making is framed by institutionalised practices and general discourses and is not value free and may even represent power imbalances and tends to favour some concerns to the distress of others [96].

The decline in agriculture and a consolidation towards fewer but larger enterprises is a general trend in Germany [97]. Tourism as an additional source of income might have slowed the process in the FLD ensuring the survival of smaller businesses [98]. However, tourism in itself is a multi-facetted sector and the future development is a subject under discussion. So far, there is a focus on soft touristic offers with small-scale enterprises that can only accommodate a limited number of visitors. An extension (e.g., by bigger hotels) would increase efficiency and degree of capacity utilisation but would also entail a rethinking of the current focus and the competitive position of current services. This issue is connected to a general discussion of privatisation of public goods for touristic purposes. Today, the shorelines of the lakes are public property and access is limited almost exclusively in nature protection areas. This might change if new touristic enterprises e.g., floating houses are established, thereby linking the development to more general questions and interests. As the whole project's main purpose is to mitigate water scarcity, it is therefore also related to expected changes due to climate change. The consequences of drought conditions are very well publicised in the media as is flood 
retention function. The importance of this aspects may rise in years to come thereby changing the focus and interest structures.

\section{Conclusions}

The reservoir system of the FLD has a multitude of impacts on natural and social spheres in the region. This offers a chance to further understand the challenges within stakeholder interests, which accompany artificial dams and reservoirs. These large infrastructure projects benefit some and harm other interests. It is therefore crucial to find suitable management strategies to cope with the challenges or to even avoid them altogether and provide optimal management for all involved stakeholders.

In many respects, the FLD is an example of a successful stakeholder cooperation network. This is due to a general agreement on predominant key interests and the opportunity of administrative stakeholders to take these interests into account. Most issues are perceived as problematic by most to all stakeholders which enables joint solution approaches and define the topics which are on the agenda. This could in part be influenced by media coverage. This confluence of interests is not present at all reservoirs, especially if hydro energy producing enterprises pursue very different goals e.g., with respect to water level changes. Still there are polar oppositions in agriculture, tourism and nature protection at the FLD. Those conflicts could be in part mitigated by the Seenlandkonferenzen of 2009 and 2010, especially concerning cyanobacteria and the communication strategies in case of restrictions on leisure activities in the water. Since the opening is quite recent, discourses in the construction and operation time could be in part reconstructed via media analysis, describing a rather positive attitude by the NüNa towards the project. Besides the reports on protests and the resettlement of mill owners in the Lake Brombach area, there is little criticism in the newspaper articles (except comments by readers). The interview partners showed more diverse interests, because of their professional connection to the reservoir focussing on topics in connection to tourism though. Since the reservoir system of the FLD was realised in the open countryside of Middle Franconia the interests and stakeholder participation are quite large. Conflicts between stakeholders centre on how economic and ecologic issues are influencing each other. Many of the issues can be directly or indirectly connected to tourism, which is a big issue on the daily agenda of stakeholders. Further research with analysis of the opinions within the general public via questionnaires would provide a basis for a holistic management approach that can be transferred to other reservoir systems with a similar focus of water transfer. A study on how the agenda of local stakeholders/media influences the management and governance in the FLD and vice versa would additionally enrich the knowledge about bottom up management issues around artificial reservoirs. These different aspects have to be incorporated within a framework for reservoir management in order to successfully allocate water resources and mitigate conflicts of interests.

Author Contributions: Conceptualisation, M.D., K.K. and R.G.; methodology, M.D., K.K., N.G. and T.H.; formal analysis, M.D., K.K., N.G. and T.H.; investigation, M.D., N.G. and T.H.; data curation, M.D., K.K., N.G. and T.H.; writing-Original draft preparation, M.D., K.K., N.G. and T.H.; writing-Review and editing, M.D., K.K., N.G. and T.H., R.G.; visualisation, M.D., T.H.; supervision, M.D., K.K., R.G.; project administration, R.G.; funding acquisition, K.K., R.G.

Funding: This research was carried out in the interdisciplinary research project of CHARM (CHAllenges of Reservoir Management).The project is supported by the Wassernetzwerk Baden-Württemberg (Water Network Baden-Wuerttemberg), which is funded by the Ministerium für Wissenschaft, Forschung und Kunst Baden-Württemberg (Ministry of Science, Research and the Arts of the State of Baden-Wuerttemberg).

Acknowledgments: The authors would like to thank Nils Riach for technical support and Urs Schüffelgen for proofreading the manuscript. The authors would also like to thank the comments and suggestions by the two anonymous reviewers of this paper. The article processing charge was funded by the German Research Foundation (DFG) and the University of Freiburg in the funding programme Open Access Publishing.

Conflicts of Interest: The authors declare no conflict of interest. The funders had no role in the design of the study; in the collection, analyses, or interpretation of data; in the writing of the manuscript, or in the decision to publish the results. 


\section{Appendix A}

Table A1. Content categories with location (lake) overlap in NüNa data.

\begin{tabular}{|c|c|c|}
\hline LAKE CATEGORY & $\begin{array}{l}\text { CONTENT CATEGORIES } \\
\text { (OVERLAPPING CODES) }\end{array}$ & $\begin{array}{l}\text { MOST IMPORTANT STAKEHOLDER } \\
\text { (OVERLAPPING CODES) }\end{array}$ \\
\hline FRANCONIAN LAKE DISTRICT & $\begin{array}{c}\text { Tourism development in numbers }(9 \% / \mathrm{n} 725) \\
\text { Tourism as an economic factor }(5 \%) \\
\text { Building projects }(5 \%)\end{array}$ & $\begin{array}{c}\text { Tourism Association }(27 \% / n=105) \\
\text { Mayors }(11 \%)\end{array}$ \\
\hline LAKE ROTH & $\begin{array}{c}\text { Water transfer to the downstream-area } \\
(18 \% / \text { n } 341) \\
\text { Water level fluctuations }(9 \%) \\
\text { Water storage }(7 \%)\end{array}$ & $\begin{array}{l}\text { Water management office }(24 \% / n=34) \\
\text { Tourism Association }(15 \%)\end{array}$ \\
\hline LAKE IGELSBACH & $\begin{array}{c}\text { Cyanobacteria }(23 \% / \mathrm{n} 96) \\
\text { Building projects }(10 \%) \\
\text { Water quality }(8 \%) \text { Beaches/bathing }(8 \%)\end{array}$ & Residents $(22 \% / n=9)$ \\
\hline LAKE ALTMUEHL & $\begin{array}{l}\text { Cyanobacteria }(17 \% / \mathrm{n} 551) \\
\text { Beaches/bathing }(5 \%) \\
\text { Species richness }(4 \%) \\
\text { Water quality }(4 \%)\end{array}$ & $\begin{array}{c}\text { Residents }(23 \% / n=61) \\
\text { Nature conservation }(12 \%)\end{array}$ \\
\hline LAKE BROMBACH & $\begin{array}{c}\text { Transfer of water downstream }(7 \% / \mathrm{n} 405) \\
\text { Water level fluctuations }(7 \%) \\
\text { Beaches/bathing }(7 \%)\end{array}$ & $\begin{array}{l}\text { Water management offices }(22 \% / n=46) \\
\text { Residents }(20 \%)\end{array}$ \\
\hline SMALL LAKE BROMBACH & $\begin{array}{l}\text { Cyanobacteria }(26 \% / \mathrm{n} 139) \\
\text { Beaches/bathing }(12 \%) \\
\text { Water quality }(10 \%)\end{array}$ & Enterprises of the tourism branch $(25 \% / n=8)$ \\
\hline LARGE LAKE BROMBACH & $\begin{array}{l}\text { Leisure water sports }(9 \% / \mathrm{n} 202) \\
\text { Infrastructure }(6 \%) \\
\text { Water level fluctuations }(6 \%)\end{array}$ & $\begin{array}{l}\text { Politics and administration }(25 \% / n=20) \\
\text { Administration union }(15 \%)\end{array}$ \\
\hline $\begin{array}{l}\text { ALL LAKE CATEGORIES } \\
\text { TOGETHER }\end{array}$ & $\begin{array}{c}\text { Cyanobacteria }(8 \% / \mathrm{n} 2459) \\
\text { Beaches/bathing }(5 \%) \\
\text { Transfer of water downstream }(5 \%) \\
\text { Water quality }(4 \%) \\
\text { Building projects }(4 \%)\end{array}$ & $\begin{array}{c}\text { Tourism Association }(17 \% / n=283) \\
\text { Residents }(13 \%) \\
\text { Water management offices (9\%) } \\
\text { Mayors (7\%) } \\
\text { Administration union }(7 \%)\end{array}$ \\
\hline
\end{tabular}

Table A2. Content categories with location (lake) overlap in interview data.

\begin{tabular}{|c|c|c|}
\hline LAKE CATEGORY & $\begin{array}{l}\text { CONTENT CATEGORIES } \\
\text { (OVERLAPPING CODES) }\end{array}$ & $\begin{array}{l}\text { MOST IMPORTANT } \\
\text { STAKEHOLDER } \\
\text { (OVERLAPPING CODES) }\end{array}$ \\
\hline FRANCONIAN LAKE DISTRICT & $\begin{array}{c}\text { Tourism as an economic factor }(7 \% / \mathrm{n} 134) \\
\text { Touristic orientation }(7 \%) \\
\text { Local recreation }(4 \%)\end{array}$ & $\begin{array}{c}\text { Tourism }(39 \% / n=41) \\
\text { Agriculture Stakeholders }(19 \%)\end{array}$ \\
\hline LAKE ROTH & $\begin{array}{c}\text { Touristic orientation }(10 \% / \mathrm{n} 87) \\
\text { Local recreation }(8 \%) \\
\text { Transfer of water downstream }(7 \%)\end{array}$ & $\begin{array}{c}\text { Tourism }(39 \% / n=23) \\
\text { Administration unions }(13 \%)\end{array}$ \\
\hline LAKE IGELSBACH & $\begin{array}{c}\text { Cyanobacteria }(40 \% / \mathrm{n} 25) \\
\text { Touristic orientation }(12 \%) \\
\text { Water level fluctuations }(12 \%)\end{array}$ & $\begin{array}{l}\text { Agriculture }(29 \% / n=7) \\
\text { Tourism }(29 \%)\end{array}$ \\
\hline LAKE ALTMUEHL & $\begin{array}{c}\text { Cyanobacteria }(17 \% / \mathrm{n} 303) \\
\text { Challenges/Conflict }(12 \%) \\
\text { Local recreation }(12 \%) \\
\text { Management }(8 \%)\end{array}$ & $\begin{array}{c}\text { Tourism }(23 \% / n=60) \\
\text { Agriculture }(15 \%) \\
\text { Administration unions }(15 \%)\end{array}$ \\
\hline LAKE BROMBACH & $\begin{array}{c}\text { Local recreation }(14 \% / \mathrm{n} 275) \\
\text { Cyanobacteria }(12 \%) \\
\text { Water level fluctuations }(4 \%)\end{array}$ & $\begin{array}{c}\text { Tourism }(31 \% / n=41) \\
\text { Water management offices }(12 \%)\end{array}$ \\
\hline SMALL LAKE BROMBACH & $\begin{array}{c}\text { Cyanobacteria }(60 \% / \mathrm{n} 40) \\
\text { Management }(13 \%) \\
\text { Touristic orientation }(5 \%)\end{array}$ & Water management offices $(43 \% / n=7)$ \\
\hline LARGE LAKE BROMBACH & $\begin{array}{c}\text { Management }(21 \% / \mathrm{n} 63) \\
\text { Local recreation }(11 \%) \\
\text { Cyanobacteria }(11 \%)\end{array}$ & $\begin{array}{l}\text { Politics and administration }(15 \% / n=34) \\
\text { Administration union }(9 \%)\end{array}$ \\
\hline ALL LAKE CATEGORIES TOGETHER & $\begin{array}{c}\text { Management }(18 \% / \mathrm{n} 912) \\
\text { Cyanobacteria }(15 \%) \\
\text { Challenges }(9 \%) \\
\text { Touristic orientation }(6 \%) \\
\text { Local recreation }(3 \%) \\
\text { Construction of the lakes }(2 \%)\end{array}$ & $\begin{array}{c}\text { Tourism }(29 \% / n=188) \\
\text { Agriculture }(16 \%) \\
\text { Politics and administration }(14 \%) \\
\text { Administration unions }(12 \%) \\
\text { Water management offices }(10 \%)\end{array}$ \\
\hline
\end{tabular}

Semi structured questionnaire of the study in German (as the language of the data acquisition)

\section{Leitfragebogen für die Expertenbefragung am Fränkischen Seenland CHARM}

\section{Einstieg}


Für welches Unternehmen/Institution sind Sie tätig? Was ist Thre Aufgabe in entsprechendem Unternehmen/In entsprechender Institution?

Wie sind Sie mit dem Fränkischen Seenland verbunden?

\section{Aktuelle und historische Einordnung}

Was für einen Einfluss hat das Fränkische Seenland auf Ihr Geschäftsfeld?

Wie sah die Situation vor der Eröffnung des Fränkischen Seenlandes aus?

Hat das Seenland Ihrer Meinung nach eher einen positiven, oder negativen Einfluss auf das Umland? Wie würden Sie die Planungsphase und Bauzeit beschreiben? Wurden Sie informiert? Fühlten Sie sich mit möglichen Befürchtungen ernstgenommen? Wurden Beteiligungsformate angeboten?

\section{Herausforderungen und Chancen im Fränkischen Seenland}

Was sind Ihrer Meinung nach die größten Herausforderungen im Bereich des Fränkischen Seenlandes? Was für positive/negative Aspekte sehen Sie in Bezug zu den verschiedenen Stauseen? Sehen Sie im Bezug zu Blaulagen/Sedimenten/Biofilmen/Klimagasen Herausforderungen?

\section{Umgang und Reaktion der verschiedenen Institutionen}

Welche Strategien verfolgt Ihr Unternehmen/ Ihre Institution in Puncto von Blaualgen/Sedimenten/Biofilmen/Klimagasen?

Welche Mittel würden Ihrer Meinung nach Benötigt, um adäquat auf die Herausforderungen durch die verschiedensten Stressoren zu reagieren

\section{Management}

Nehmen Sie eine Managementstrategie für die Stauseen wahr?

Wenn ja, wie äußert sich diese?

Wie sehen Sie den Betrieb/ das Management des Stauseesystems? Birgt er/es Vor- oder Nachteile?

\section{Stakeholder und offene Punkte}

Welche anderen Stakeholder sehen Sie als wichtig an?

Gibt es noch wichtige Punkte über die noch nicht gesprochen wurde, oder die Sie gerne noch besonders betonen möchten?

Table A3. Alias and anonymised interview partners of the study.

\begin{tabular}{cc}
\hline Alias & Interview Partner (Anonymised) \\
\hline Nature Protection 1 & Two Interviewees from an NGO nature protection agency (one female, one male) \\
Nature Protection 2 & Two Interviewees from an NGO nature protection agency (two females) \\
Nature Protection 3 & Landscape conservation association (one male) \\
Tourism 1 & Administration union in FLD (one male) \\
Tourism 2 & Administration union in FLD (one male) \\
Tourism 3 & Tourism association (one male) \\
Tourism 4 & Administration union (second interview with same person; one male) \\
Tourism 5 & Tourism association (second interview with same person; one male) \\
Tourism 6 & Administration union in FLD (one male) \\
Tourism 7 & Tourism association (one woman) \\
Administration 1 & District office WUG (one male) \\
Administration 2 & District office Roth (one male) \\
Administration 3 & Public health office WUG (one male) \\
Administration 4 & Public health office WUG (one male) \\
Administration 5 & Administrational office WUG (one male) \\
Association/Organisation 1 & NGO Association water guard Ansbach (one male) \\
Association/Organisation 2 & Heritage society (one female, one male) \\
Agriculture (Associations) 1 & Agriculture association (one male) \\
Agriculture (Associations) 2 & Agriculture association (two male) \\
Management 1 & Management (one female) \\
Management 2 & Management (one male) \\
Tourism Enterprises 1 & Tourism Enterprise (one male) \\
\hline
\end{tabular}




\section{References}

1. Glaser, R. Global change. Das neue Gesicht der Erde; Primus Verlag: Darmstadt, Germany, 2014; ISBN 9783863120993.

2. DPA. Wasserknappheit: Umweltbundesamt warnt vor Streit ums Trinkwasser. 5 July 2019. Available online: https://www.zeit.de/wirtschaft/2019-07/trinkwasser-knappheit-sommer-trockenheitumweltbundesamt (accessed on 10 July 2019).

3. Zarfl, C.; Lumsdon, A.E.; Berlekamp, J.; Tydecks, L.; Tockner, K. A global boom in hydropower dam construction. Aquat Sci 2015, 77, 161-170. [CrossRef]

4. Blackbourn, D.; Rennert, U. Die Eroberung der Natur. Eine Geschichte der deutschen Landschaft, 3rd ed.; Pantheon: München, Germany, 2008; ISBN 9783570550632.

5. International Commission on Large Dams. Talsperren in Deutschland; Springer Vieweg: Wiesbaden, Germany, 2013; ISBN 978-383-48210-7-2.

6. Carnea, M.M. Hydropower Dams and Social Impacts. A Sociological Perspective. 1997. Available online: http://documents.worldbank.org/curated/en/446311468761673943/Hydropower-dams-and-socialimpacts-a-sociological-perspective (accessed on 25 July 2019).

7. Weber, F. Konflikte um die Energiewende. Vom Diskurs zur Praxis, 1st ed.; Springer VS: Wiesbaden, Germany, 2018; ISBN 9783658205249.

8. Moore, D.; Dore, J.; Gyawali, D. The World Commission on Dams + 10: Revisiting the Large Dam Controversy. Water Alternatives 2010, 3, 3-13. Available online: https:/dlc.dlib.indiana.edu/dlc/bitstream/handle/10535/ 7036/3-2-2.pdf? sequence=1 (accessed on 25 July 2019).

9. Palmer, M.A.; Lettenmaier, D.P.; Poff, N.L.; Postel, S.L.; Richter, B.; Warner, R. Climate change and river ecosystems: protection and adaptation options. Environ. Manage. 2009, 44, 1053-1068. [CrossRef] [PubMed]

10. Beckers, F.; Haun, S.; Gerbersdorf, S.U.; Noack, M.; Dietrich, D.; Martin-Creuzburg, D.; Peeters, F.; Hofmann, H.; Glaser, R.; Wieprecht, S. CHARM - CHAllenges of Reservoir Management - Meeting environmental and social requirements. Hydrolink 2018, 16-18.

11. Peeters, F.; Encinas Fernandez, J.; Hofmann, H. Sediment fluxes rather than oxic methanogenesis explain diffusive CH4 emissions from lakes and reservoirs. Sci. Rep. 2019, 9, 243. [CrossRef]

12. World Commission on Dams. Dams and development. A new framework for decision-making; Earthscan: London, UK, 2000; ISBN 1853837989.

13. Tilt, B.; Braun, Y.; He, D. Social impacts of large dam projects: A comparison of international case studies and implications for best practice. J. Environ. Manage. 2009, 90 (Suppl. 3), 249-257. [CrossRef]

14. Nguyen, H.; Pham, T.; Lobry de Bruyn, L. Impact of Hydroelectric Dam Development and Resettlement on the Natural and Social Capital of Rural Livelihoods in Bo Hon Village in Central Vietnam. Sustainability 2017, 9, 1422. [CrossRef]

15. Rotilio, M.; Marchionni, C.; de Berardinis, P. The Small-Scale Hydropower Plants in Sites of Environmental Value: An Italian Case Study. Sustainability 2017, 9, 2211. [CrossRef]

16. Kirchherr, J.; Charles, K.J. The social impacts of dams: A new framework for scholarly analysis. Environmental Impact Assessment Review 2016, 60, 99-114. [CrossRef]

17. Schultze, M.; Pokrandt, K.-H.; Hille, W. Pit lakes of the Central German lignite mining district: Creation, morphometry and water quality aspects. Limnologica 2010, 40, 148-155. [CrossRef]

18. Koschorreck, M.; Kleeberg, A.; Herzsprung, P.; Wendt-Potthoff, K. Effects of benthic filamentous algae on the sediment-water interface in an acidic mining lake. Hydrobiologia 2007, 592, 387-397. [CrossRef]

19. Gross, M. Ignorance, research and decisions about abandoned opencast coal mines. Sci. and Pub. Pol. 2010, 37, 125-134. [CrossRef]

20. Wasserwirtschaftsamt Ansbach. Naturschutzgebiete am Brombachsee - Wasserwirtschaftsamt Ansbach. Available online: https://www.wwa-an.bayern.de/ueberleitung/fraenkische_seen/brombachsee/naturschutz/ index.htm (accessed on 6 July 2018).

21. Brix, C. Neues fränkisches Seenland. Hydrogeologische Untersuchungen zu den Grundwasser-Verhältnissen nach Einstau der Talsperren; Erlangen, Univ., Diss.: Nürnberg, Germany, 1995.

22. Cohen, B.C. The Press and foreign policy, Reprinted; Univ. of California: Berkeley, CA, USA, 1993; ISBN 087772346X. 
23. McCombs, M.E.; Shaw, D.L. The Evolution of Agenda-Setting Research: Twenty-Five Years in the Marketplace of Ideas. J. Commun. 1993, 43, 58-67. Available online: https://www.jstor.org/stable/pdf/10.5325/jinfopoli.6. 2016.0129.pdf (accessed on 25 July 2019). [CrossRef]

24. Baumgartner, F.R.; Green-Pedersen, C.; Jones, B.D. Comparative studies of policy agendas. J. Eur. Public Policy 2006, 13, 959-974. [CrossRef]

25. Baumgartner, F.R.; Jones, B.D. Agendas and instability in American politics; Univ. of Chicago Press: Chicago, IL, USA, 2004; ISBN 0226039390.

26. Liu, X.; Lindquist, E.; Vedlitz, A. Explaining Media and Congressional Attention to Global Climate Change, 1969-2005: An Empirical Test of Agenda-Setting Theory. Political Research Quarterly 2011, 64, 405-419. [CrossRef]

27. McCombs, M.E.; Shaw, D.L. The Agenda-Setting Function of Mass Media. Public Opin. Q. 1972, 36, 176-187. Available online: https://www.jstor.org/stable/2747787?origin=JSTOR-pdf\&seq=1\#metadata_info_ tab_contents (accessed on 25 July 2019). [CrossRef]

28. Tosun, J.; Schaub, S. Mobilization in the European Public Sphere: The Struggle Over Genetically Modified Organisms. Rev. Policy Res. 2017, 34, 310-330. [CrossRef]

29. Sciarini, P.; Tresch, A. The political agenda-setting power of the media: the Europeanization nexus. J. Eur. Public Policy 2019, 26, 734-751. [CrossRef]

30. Briemle, K. The "New Franconian Lake District": A Landscape Created by Human Hand; Anthos: Zurich, Switzerland, 1996.

31. Maurer, R. Nur Gewinner durch das Fränkische Seenland. Available online: http://www.nordbayern. de/region/wei\%C3\%9Fenburg/nur-gewinner-durch-das-frankische-seenland-1.7571477 (accessed on 6 July 2018).

32. W.A. Die Überleitung von Altmühl- und Donauwasser in das Regnitz-Main-Gebiet. Available online: https://www.zv-brombachsee.de/ueberleitung/ (accessed on 1 September 2019).

33. Kirchherr, J.; Pohlner, H.; Charles, K.J. Cleaning up the big muddy: A meta-synthesis of the research on the social impact of dams. Environ. Impact Assess. Rev. 2016, 60, 115-125. [CrossRef]

34. Bär, S. Ganzheitliches Tourismus-Marketing. Die Gestaltung regionaler Kooperationsbeziehungen; Deutscher Universitäts-Verlag: Wiesbaden, Germany, 2006; ISBN 978-3-8350-0275-3.

35. Hopfinger, H. Das „Neue Fränkische Seenland“: ein touristisches Großprojekt als regionalplanerische Erfolgsstory. In Tourismus: Herausforderung für die Region; Struck, E., Ed.; Passauer Kontaktstudium Geographie: Passau, Germany, 2015; pp. 97-111.

36. Diaz-Bone, R. Kritische Diskursanalyse: Zur Ausarbeitung einer problembezogenen Diskursanalyse im Anschluss an Foucault. Siegfried Jäger im Gespräch mit Rainer Diaz-Bone. Forum Qualitative Sozialforschung/Forum: Qualitative Social Research. 2006, 7. Available online: http://www.qualitative-research. net/index.php/fqs/rt/printerFriendly/148/325 (accessed on 25 July 2019).

37. Mattissek, A.; Pfaffenbach, C.; Reuber, P. Methoden der empirischen Humangeographie, 2nd ed.; Westermann: Braunschweig, Germany, 2013; ISBN 9783141603668.

38. Foucault, M.; Konersmann, R. Die Ordnung des Diskurses, Erweiterte Ausgabe, 14th ed.; FISCHER Taschenbuch: Frankfurt am Main, Germany, 2017; ISBN 9783596100835.

39. Jäger, S. Kritische Diskursanalyse. Eine Einführung, 7th ed.; Unrast: Münster, Germany, 2015; ISBN 978-3-89771-761-9.

40. Waitt, G.R. Doing Dicourse Analysis. In Qualitative research methods in human geography, 4th ed.; Hay, I., Ed.; Oxford University Press: Don Mills, ON, Canada, 2016; pp. 163-191. ISBN 9780199010905.

41. Maurer, M.; Reinemann, C. Medieninhalte - Eine Einführung; VS Verlag für Sozialwissenschaften: Wiesbaden, Germany, 2006; ISBN 978-3-531-90179-4.

42. Früh, W. Inhaltsanalyse. Theorie und Praxis, 8th ed.; UVK Verlagsgesellschaft mbH; UVK/Lucius: Konstanz, München, Germany, 2015; ISBN 9783825243777.

43. Klein, H. Zeitungsartikel. In Handbuch Methoden der empirischen Sozialforschung; Baur, N., Blasius, J., Eds.; Springer VS: Wiesbaden, Germany, 2014; pp. 841-846. ISBN 9783531178097.

44. Mayer, H.O. Interview und schriftliche Befragung. Grundlagen und Methoden empirischer Sozialforschung, 6th ed.; Oldenbourg Wissenschaftsverlag: München, Germany, 2013; ISBN 9783486717624.

45. Kruse, J. Qualitative Interviewforschung. Ein integrativer Ansatz; Beltz Juventa: Weinheim u.a., Germany, 2014; ISBN 978-3-7799-2901-7. 
46. Qualitative Forschung. Ein Handbuch, 12th ed.; Flick, U.; Kardorff, E.V.; Steinke, I. (Eds.) Originalausgabe; rowohlts enzyklopädie im Rowohlt Taschenbuch Verlag: Reinbek bei Hamburg, Germany, 2017; ISBN 9783499556289.

47. Nohl, A.-M. Interview und Dokumentarische Methode. Anleitungen für die Forschungspraxis, 5th ed.; Springer VS: Wiesbaden, Germany, 2017; ISBN 9783658160791.

48. Mayring, P. Qualitative Inhaltsanalyse. Grundlagen und Techniken, 12th ed.; Beltz: Weinheim, Germany, 2015; ISBN 3407257309.

49. IVW. Run of Nürnberger Nachrichten (Mo-Sa). Available online: https://www.ivw.eu/aw/print/qa/titel/1244? quartal\%5B20181\%5D=20181\&quartal\%5B20182\%5D=20182\&quartal\%5B20183\%5D=20183\&quartal\% 5B20184\%5D=20184\&quartal\%5B20191\%5D=20191\#views-exposed-form-aw-titel-az-aw-az-qa (accessed on 5 July 2019).

50. Mayring, P. Einführung in die qualitative Sozialforschung, 6th ed.; Beltz: Weinheim, Germany; Basel, Switzerland, 2016.

51. VERBI Software. MAXQDA 2018; VERBI Software: Berlin, Germany, 2017.

52. Kuckartz, U. Einführung in die computergestützte Analyse qualitativer Daten, 3rd ed.; VS Verlag für Sozialwissenschaften: Wiesbaden, Germany, 2010; ISBN 3531166611.

53. Haas, T.; Stork, K. Hochwasser - Schutz - Konflikte. eine transdisziplinäre Perspektive; Universitätsverlag Winter: Heidelberg, Germany, 2016; ISBN 978-3-8253-6569-1.

54. Kromrey, H.; Roose, J.; Strübing, J. Empirische Sozialforschung. Modelle und Methoden der standardisierten Datenerhebung und Datenauswertung mit Annotationen aus qualitativ-interpretativer Perspektive, 13th ed.; UVK; UVK/Lucius: Konstanz, München, Germany, 2016; ISBN 9783825286811.

55. Auer, H.M. Grenzen des Wachstums Das Fränkische Seenland und der sanfte Tourismus. Nürnberger Nachrichten. 24 July 2000. Available online: https://www.wiso-net.de/document/NN_ _D88130A0E0988A53C1256E4C005CEEE3 (accessed on 25 July 2019).

56. Falk, W. Badefreuden am algenfreien Sandstrand. Nürnberger Nachrichten. 8 July 2010. Available online: https: //www.wiso-net.de/document/NN_6FB7E17DDB58E1EBC125775A000A2C39 (accessed on 25 July 2019).

57. Huisman, J.; Codd, G.A.; Paerl, H.W.; Ibelings, B.W.; Verspagen, J.M.H.; Visser, P.M. Cyanobacterial blooms. Nature Reviews Microbiology 2018, 16, 471-483. [CrossRef] [PubMed]

58. Auer, H.M. Algenfrust ohne Ende. Nürnberger Nachrichten [Online]. 7 July 2011. Available online: https://www.wiso-net.de/document/NN_17845D3F3150A517C12578C60009EC9C (accessed on 25 July 2019).

59. BayBadeGewV: Bayerische Badegewässerverordnung: Verordnung über die Qualität und die Bewirtschaftung der Badegewässer. Bayerische Badegewässerverordnung - BayBadeGewV. 2008. Available online: https: //www.gesetze-bayern.de/Content/Document/BayBadeGewV (accessed on 25 July 2019).

60. Abspacher, P.; Auer, H.M. Gut und preiswert, nicht unbedingt billig: Fränkisches Seenland setzt auf Qualitätsoffensive - Starke Abhängigkeit vom Wetter ist ein Kernproblem. Nürnberger Nachrichten. 25 September 2010. Available online: https://www.wiso-net.de/document/NN_ _EEABF8921921A765C12577A9000A2E35 (accessed on 25 July 2019).

61. Auer, H.M. Therapie für den See. Nürnberger Nachrichten. 14 November 2009. Available online: https: //www.wiso-net.de/document/NN_7D0E13D142D008DFC125766E000F9827 (accessed on 25 July 2019).

62. W.A. Algen schaden dem Ruf des Seenlands. Nürnberger Nachrichten. 16 October 2009. Available online: https://www.wiso-net.de/document/NN_3ED80589A3099EE0C1257651000A31FA (accessed on 25 July 2019).

63. Maurer, R. Gemeinden hungern Algen aus. Nürnberger Nachrichten. 22 May 2010. Available online: https://www.wiso-net.de/document/NN_8E90A96DED15B156C125772B000A2827 (accessed on 25 July 2019).

64. Auer, H.M. Nicht nur die Algen drohen den Ruf zu ruinieren. Nürnberger Nachrichten. 30 September 2010. Available online: https://www.wiso-net.de/document/NN_93E11A017B26EE8BC12577AE000B9B93 (accessed on 25 July 2019).

65. W.A. Bauern schuld an den Algen? Nürnberger Nachrichten. 2 August 2014. Available online: https: //www.wiso-net.de/document/NN_B46AE964C34279F4C1257D27007F3DDF (accessed on 25 July 2019).

66. Rach, U. „Bauern wehren sich gegen Behauptung, durch Überdüngung der Felder die Algenplage im Altmühlseeauszulösen Tonnenweise Vogelkot Ursache für Giftalgen? "“Eine leichtfertige und pauschale Schuldzuweisung der Wasserwirtschaft““ - Künftig Raubfischbesatz als Mittel gegen die Misere „. Nürnberger Nachrichten. 30 August 2001. Available online: https://www.wiso-net.de/document/NN_ _8E3CDB416C205C74C1256E4C005FB79D (accessed on 25 July 2019). 
67. W.A. Sorge um die Kinder: Kein Verbot, aber Badewarnung für den Altmühlsee. Nürnberger Nachrichten. 7 August 2009. Available online: https://www.wiso-net.de/document/NN_ _AF1040F63E8FE7C2C125760B000FAFF4 (accessed on 25 July 2019).

68. W.A. Altmühlsee soll algenfrei werden Bessere Sicht Wasserwirtschaftsamt startet Versuch - Sind Weißfische schuld? Nürnberger Nachrichten. 3 May 2001. Available online: https://www.wiso-net.de/document/NN_ _CAF4BCE19877878AC1256E4C005EC6BA (accessed on 25 July 2019).

69. Falk, W. Starkes Wachstum der giftigen Blaualgen führte erstmals zu dem drastischen Schritt Badeverbot für den Altmühlsee: Gesundheitsamt warnt vor gesundheitlichen Risiken - Einendreifach überhöhten Wert gemessen. Nürnberger Nachrichten. 27 August 2001. Available online: https://www.wiso-net.de/document/ NN__DFB6FD1D655D7AD4C1256E4C005FB05F (accessed on 25 July 2019).

70. Interview Administration 5. Chances and Challenges at the Franconian Lake District. Personal communication, 2 December 2018.

71. Interview Tourism 4. Cyanobacteria at the Franconian Lake District. Personal communication, 29 March 2018.

72. Kleinhenz, A.; Koenig, A. Home ranges and movements of resident graylag geese (Anser anser) in breeding and winter habitats in Bavaria, South Germany. PLoS ONE 2018, 13, e0202443. [CrossRef] [PubMed]

73. Maurer, R. Graugänse fühlen sich wohl im Seenland: Population steigt und damit wächst das Problem verkoteter Liegewiesen. Weißenburger Tagblatt. 7 March 2011. Available online: https://www.nordbayern.de/ region/wei\%C3\%9Fenburg/grauganse-fuhlen-sich-wohl-im-seenland-1.1047370 (accessed on 9 July 2019).

74. König, A.; Kleinhenz, A.; Hof, C.; Carstensen, N. Ökologie und Management von Wildgänsen in Bayern; Abschlussbericht zur Vorlage Bayerisches Staatsministerium für Landwirtschaft und Forsten: Freising, Germany, 2013.

75. Interview Associations (Agriculture) 1. Chances and Challenges at the Franconian Lake District/Agriculture (Association). Personal communication, 18 July 2018.

76. Interview Association/Organisation 2. Chances and Challenges at the Franconian Lake District. Personal communication, 2 December 2018.

77. Interview Nature Protection 2. Chances and Challenges at the Franconian Lake District/Nature Protection. Personal communication, 3 December 2018.

78. Interview Tourism 2. Chances and Challenges at the Franconian Lake District/Tourism. Personal communication, 18 July 2018.

79. Wasserwirtschaftsamt Ansbach. Mühlen im Brombachtal. Wasserkraft sägte Holz und mahlte Getreide, n.d. Available online: https:/www.wwa-an.bayern.de/ueberleitung/fraenkische_seen/brombachsee/muehlen/ index.htm (accessed on 18 July 2019).

80. Auer, H.M. Das Fränkische Seenland ist nicht in erster Linie als ein Ferienparadies gebaut worden Wasserspeicher mit Zusatznutzen Überleitung hilft dem trockenen Nordbayern - Der Hauptdamm ist mit Messeinrichtungen gespickt. Nürnberger Nachrichten. 7 July 2000. Available online: https: //www.wiso-net.de/document/NN_06645A03A3EDEFEAC1256E4C005CDCB3 (accessed on 25 July 2019).

81. Auer, H.M. Freier Zugang zu den Ufern: Fränkisches Seenland lernte aus den Fehlern in Oberbayern. Nürnberger Nachrichten. 16 April 2016. Available online: https:/www.wiso-net.de/document/NN_ _5C2D88A04F013D06C1257FA4007EFAAA (accessed on 25 July 2019).

82. Auer, H.M.; Donauwasser für Franken. Nürnberger Nachrichten. 14 September 1992. Available online: https://www.wiso-net.de/document/NN_7702B18B71F908E4C1256E4B003C8CBE (accessed on 25 July 2019).

83. Dolman, A.M.; Rücker, J.; Pick, F.R.; Fastner, J.; Rohrlack, T.; Mischke, U.; Wiedner, C. Cyanobacteria and cyanotoxins: The influence of nitrogen versus phosphorus. PLoS ONE 2012, 7, e38757. [CrossRef] [PubMed]

84. Paerl, H.W.; Otten, T.G. Harmful cyanobacterial blooms: Causes, consequences, and controls. Microb. Ecol. 2013, 65, 995-1010. [CrossRef] [PubMed]

85. Awojobi, O.; Jenkins, G.P. Were the hydro dams financed by the World Bank from 1976 to 2005 worthwhile? Energy Policy 2015, 86, 222-232. [CrossRef]

86. Tilt, B.; Gerkey, D. Dams and population displacement on China's Upper Mekong River: Implications for social capital and social-ecological resilience. Global Environmental Change 2016, 36, 153-162. [CrossRef]

87. Wang, P.; Lassoie, J.P.; Dong, S.; Morreale, S.J. A framework for social impact analysis of large dams: A case study of cascading dams on the Upper-Mekong River, China. J. Environ. Manage. 2013, 117, 131-140. [CrossRef] 
88. Interview Management 1. Chances and Challenges at the Franconian Lake District. Personal communication, 17 July 2018.

89. Bohlen, C.; Lewis, L.Y. Examining the economic impacts of hydropower dams on property values using GIS. J. Environ. Manage. 2009, 90 (Suppl. 3), 258-269. [CrossRef]

90. Eichhorn Wolfgang. Agenda Setting Prozesse. Eine theoretische Analyse individueller und gesellschaftlicher Themenstrukturierung. 2005. Available online: http://epub.ub.uni-muenchen.de/archive/00000734/.

91. Auer, H.M. Selten hat ein Mammutprojekt so wenig Widerspruch und Widerstand hervorgerufen wie das FränkischeSeenland: Freizeittrubel geht an der Schnatterente vorbei Konsequente Nutzungstrennung kommt den ökologischen Ruhezonen zugute - "Mit Hirnschmalz sehenswerte Lösungen gefunden“. Nürnberger Nachrichten. 17 July 2000. Available online: https://www.wiso-net.de/document/NN_ _BF8CD7DB3966CD31C1256E4C005CE6F9 (accessed on 25 July 2019).

92. Abspacher, P. Seenland braucht dringend Aufwind: Mehr gehobene Hotels, Restaurants auf dem Wasser und Aussichtstürme sollen Urlaubsziel aufwerten. Nürnberger Nachrichten. 2 September 2010. Available online: https://www.wiso-net.de/document/NN_FFC9AD9ABCE7AE5AC1257792000A2C6E (accessed on 25 July 2019).

93. Schiller, J. Sehr gefährliche Hotelbau-Ideen. Nürnberger Nachrichten. 29 September 2010. Available online: https://www.wiso-net.de/document/NN_736B4D2EA3955B68C12577AD000A2221 (accessed on 25 July 2019).

94. Heilbronner, D. Der Erfolg des Volksbegehrens ist keine Überraschung. Nürnberger Nachrichten. 30 July 1990. Available online: https://www.wiso-net.de/document/NN_61BB9927E002FAEBC1256E4A005A73B3 (accessed on 25 July 2019).

95. Interview Nature Protection 3. Chances and Challenges at the Franconian Lake District/Nature Protection. Personal communication, 3 December 2018.

96. Costa, A.; Caldas, J.C.; Coelho, R.; Ferreiro, M.d.F.; Gonçalves, V. The Building of a Dam: Value Conflicts in Public Decision-Making. Env. Values 2016, 25, 215-234. [CrossRef]

97. Gindele, N.; Kaps, S.; Doluschitz, R. Strukturelle Veränderungen in der Landwirtschaft: Reaktion der landwirtschaftlichen Betriebsleiter sowie ableitbare Konsequenzen für den Landwirt als Unternehmer. J. Socio-Econ. Agric. 2015, 8.

98. Interview Administration 1. Chances and Challenges at the Franconian Lake District. Personal communication, 20 July 2018. 